\title{
実大米松集成材の曲げクリープ性状 \\ BENDING CREEP BEHAVIOUR OF FULL SIZE DOUGLAS FIR GLULAM BEAMS
}

\author{
木 村 衛*, 楠 寿 博**, 鴐 海 四 郎*** \\ Mamoru KIMURA, Toshihiro KUSUNOKI and Shirou OSHIUMI
}

\begin{abstract}
An experimental study on the bending creep behaviour of full-size douglas-fir glulam beam was made under non-controlled sheltered environment for 9 years for the purpose of clarifying the efficient way of defining creep deflection curve in relation to the load duration. Two experiments were carried out at stress level of 0.3 and 0.5 , which is the ratio of bending stress to static bending strength. The latter concluded creep failure after 4 years loading. In this paper, the results of these experiments are presented.

For formularizing the creep deflection curve, it is necessary that the load duration should be at least more than one and a half year, but at the same time it is to be desired that first six months data is ignored. After 9 years loading of stress ratio of 0.3 , unloading was made, and it showed that the flexural rigidity remained unchanged.
\end{abstract}

Reywords : Glulam beam, Bending creep, Creep failure, Creep deflection curve, Creep recovery 集成材梁, 曲げクリープ, クリープ破壊, クリープ変形曲線, クリープ回復

1. 序

従来の比較的小規模な木構造建築では梁の曲げクリープ変形が問 題視されることは少なかったが、近年増加している集成材による大 規模木構造建築では、外観、機能性及び力学的な安全性の面から曲 げクリープ変形が無視しえない場合の生じる可能性がある。現行の 日本建築学会木質構造設計規準(5)（以下学会規準と称す）では集成 材に於ける曲げクリープ変形の評価法については一般木材に準じた 扱いとなっている。一方、木材を対象とした従来の曲げクリープ実 験は、小断面の無欠点材を試験体としたものが多く(6)(7)他、実大集成 材に対して実施したものは、その装置構成或いは長期間実施の困難 さのために非常に少ない状況にある。

杉材などを用いた既往の研究(6) (11)によれば、木材の曲げクリープ 限度は静的曲げ強度の 40〜60\%程度であるとされている。クリープ 限度は、長期間の荷重に対して木材がクリープ破壊しない荷重レべ ルの最大值であるが、学会規準では曲げ強度の $5 \%$ 下限值の概ね 3 分の 1 を設計上のクリープ限度と見なし、これを長期許容応力度と している。

集成材に対して実施した例としては、Jelena らによる実験 ${ }^{(12) や ~}$ Ranta-Maunus らによる実験 ${ }^{(13)}$ がある。前者は高い湿度条件下ではク リープ変形が 1 年間で通常の 2 倍に達する場合があることを示して
いる。後者は最大曲げ応力度が $2 \sim 4 \mathrm{~N} / \mathrm{mm}^{2}$ とやや低い応力度レベル の実験を実大集成材で約 8 年間実施している。我が国では実大から 松集成材を用いた高橋らによる約 1 年半の実験 ${ }^{(14)}$ がある。

このような状況を踏まえ、現実に近い条件を与えた場合の集成材 について長期的な曲げクリープ性状の把握と、クリープ限度の確認 を目的として、実大米松集成材を用いた 9 年間の長期載荷実験を実 施した。本研究では特に学会規準による長期許容応力度レベルと、 小断面木材を用いた既往の研究によるクリープ限度レベルに着目し、 2 ケースの実験を対象とした。

本論ではこの 9 年間に及ぶクリープデータの紹介とともに、クリ 一プ予測線を設定するための、測定期間の有効性について言及する。

\section{2. 実験概要}

\section{$2-1$. 試験体概要}

試験体は断面 $120 \times 396 \mathrm{~mm}$ 、全長 $6 \mathrm{~m}$ の旧 JAS による 1 級構造用集 成材である。素材は米松で、ラミナ厚が $33 \mathrm{~mm}$ 、積層数は 12 である。 ラミナ構成は、外側 2 層を 2 等、内側 4 層を 4 等、中間層を 3 等と した。試験体製作に用いるラミナの抜き取り素材試験を行なった。 結果を図 1 に示す。本試験体では目視及びグレーディングマシーン に依った等級分けに有意な差が認められなかった。平均で圧縮強度 
$35.6 \mathrm{~N} / \mathrm{mm}^{2}$ 、引張強度 $45.0 \mathrm{~N} / \mathrm{mm}^{2}$ であった。

試験体数は、載荷荷重レベルに対してそれぞれ 1 体ずつ、合計 2 体とした。ただし、クリープ実験に先立って試験体の力学性状を把 握しておくため、同条件で製作された集成材を用いて 2 点集中載荷 による静的曲げ破壊実験を行なった。その荷重一変形関係を図 2 に 示す。最大耐力は、素材試験から評価した值にほほ対応している。 これより曲げ強度を求めると、 $43.62 \mathrm{~N} / \mathrm{mm}^{2}$ となる。後述するクリー プ限度の荷重レベルに対し、せん断変形を考慮してヤング率 $\mathrm{E}$ を次 式により求めると、約 $11,000 \mathrm{~N} / \mathrm{mm}^{2}$ の值が得られた。

$$
\delta_{\alpha=0.5}=\left[\frac{\mathrm{a}\left(3 \mathrm{~L}^{2}-4 \mathrm{a}^{2}\right)}{24 \mathrm{EI}}+\kappa \frac{\mathrm{a}}{\mathrm{GA}}\right] \frac{\mathrm{P}_{\alpha=0.5}}{2}
$$

ここに、L、aは、全スパン長およびせん断スパン長であり、A，Iは 断面積と断面二次モーメント、 $\delta_{\alpha=0.5}$ はクリープ限度の荷重 $\mathrm{P}_{\alpha=0.5}$ における変形である。なお、断面の形状係数 $\kappa$ 、せ九断弾性係数 $\mathrm{G}$ はそれぞれ 6/5、E/15 とした。長期許容曲げ応力度を曲げ強度の $1 / 3$ とすれば $14.54 \mathrm{~N} / \mathrm{mm}^{2}$ となり、ヤング率とともに学会規準に於ける 1 級構造用集成材の規定値にほぼ等しい值であった。

なお、接触式の含水率計を用いて載荷直前に 2 試験体の表面含水 率を測定したところ、長期荷重レベル対応のものが $11.3 \%$ 、クリー プ限度の荷重レベル対応のものが $12.0 \%$ あった。これらの值は各 試験体に於いて任意の 5 点で測定した含水率の平均である。

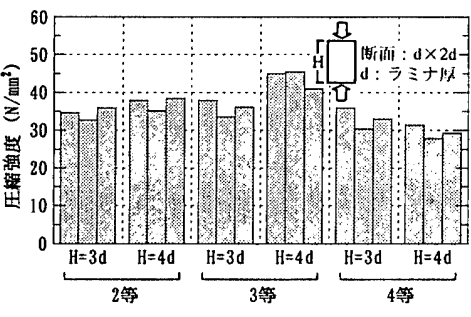

(a) 圧縮試験

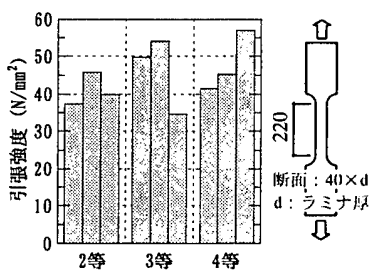

(b) 引張試験
図 1 ラミナの素材試験結果

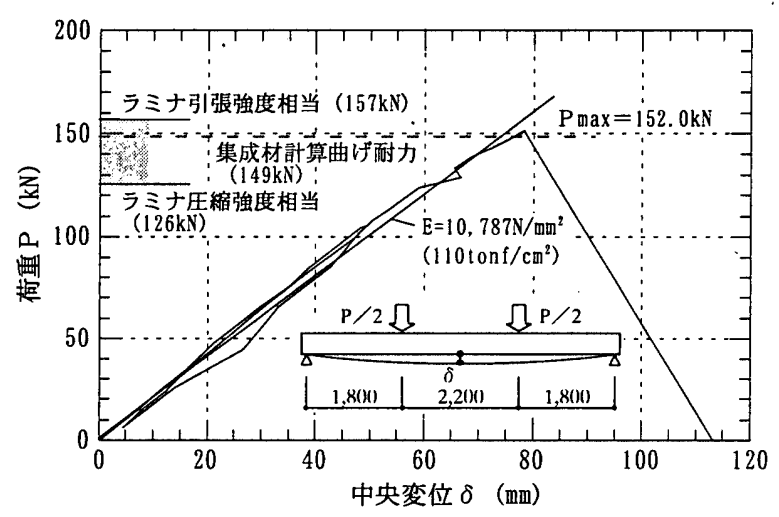

図 2 試験体の静的荷重一変形関係

\section{$2-2$. 載荷装置}

載荷装置はそれぞれの荷重レベル別に製作している。設置場所は (財)日本住宅・木材技術センターの旧試験研究所実験棟内で、空調 はなく寧ろ外気に直接触れるような環境である。装置の概要を図 3、 写真 1 に示す。各試験体は 2 基のコンクリート製支持架台上に置か
れている。境界条件は単純梁形式とし、一端ピン、他端ローラーと した。荷重には長さ $5 \mathrm{~m}$ に切り揃えた鋼矢板（FSP-3 型）を使用し た。本鋼矢板は幅 $400 \mathrm{~mm}$ 、重さは 1 枚当たり約 $3,000 \mathrm{~N}$ である。荷重 レベルはこの鋼矢板の枚数により調節した。吊り金物、長ボルト及 び上下一対の受け金物の組合せにより鋼矢板を試験体に載荷した。

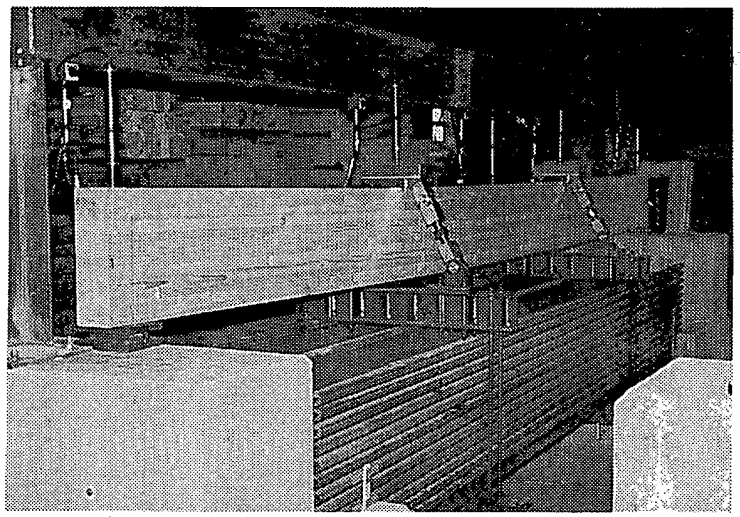

写真 1 クリープ実験状況（応力比 $\alpha=0.5 ）$

\section{$2-3$. 載荷方法}

載荷は 2 点集中加力形式である。支持点から載荷点までのせん断 スパン長さ $\mathrm{a}=1.8 \mathrm{~m}$ は、等分布荷重を受ける場合の曲げモーメント 分布に近似させたもので、せん断破買が曲げ破壊に先行しないとい う条件も含んでいる。先に行った曲け破壊実験はこれに対応させて いる。

長期荷重レベルは曲げ強度に対する応力比 $\alpha$ を 0.3 として、鍾の 重量は $44.60 \mathrm{kN}$ とした。文献 10 によれば、応力比 0.4 ならば変位は 安定し、応力比 0.6 の時にはクリープ破壊したとされている。そこ でクリープ限度を想定した荷重レベルは応力比 0.5 とした。この時 の鍾の重量は74.32kNである。鋼矢板は 1 枚ずつ正確に重量を計り、 吊り金物等の鋼材の重量を考慮して必要枚数を算出した。この時、 端数の不足分は板錘によって補充している。

図 3(c), (d)にそれぞれの応力比の場合の載荷装置構成を示す。 4 台 の手動油圧ジャッキ（揚程 $100 \mathrm{~mm}$ ）上に受け金物を置き、この上に 所定量の鋼矢板を積み上げる。長さ調節ネジで吊り金物を試験体に 荷重がかからない程度に接触させ、この時点を変位測定の基点とす る。4 台のジャッキはそれぞれにセットされたジャッキストローク 制御用変位計により、鋼矢板の水平を保つように徐々にジャッキダ ウンする。ジャッキダウンの開始が実験開始時刻となる。

載荷は 2 体とも 1991 年 3 月 26 日に実施した。なお、応力比 0.3 の試験体は、午前 11 時 9 分、0.5 の試験体は午後 1 時 31 分をクリー プ測定のスタートとしている。

長期荷重レベルの試験体については、9 年目の 2000 年 6 月 15 日 午前 10 時 40 分に一旦除荷し、 1 ケ月後の 7 月 17 日午前 1 時 46 分 に再載荷し、更に午後 2 時 0 分に再除荷して実験を終了した。

\section{$2-4$. 測定方法}

測定は試験体の鉛直変位、奏施場所の温湿度について行う。鉛直 変位は、試験体中央（1 ケ所）、支持点（2 ケ所）、荷重点（2 ケ所） の合計 5 ヶ所つにいて、変位計により測定する (図 3 (a)参照)。こ 


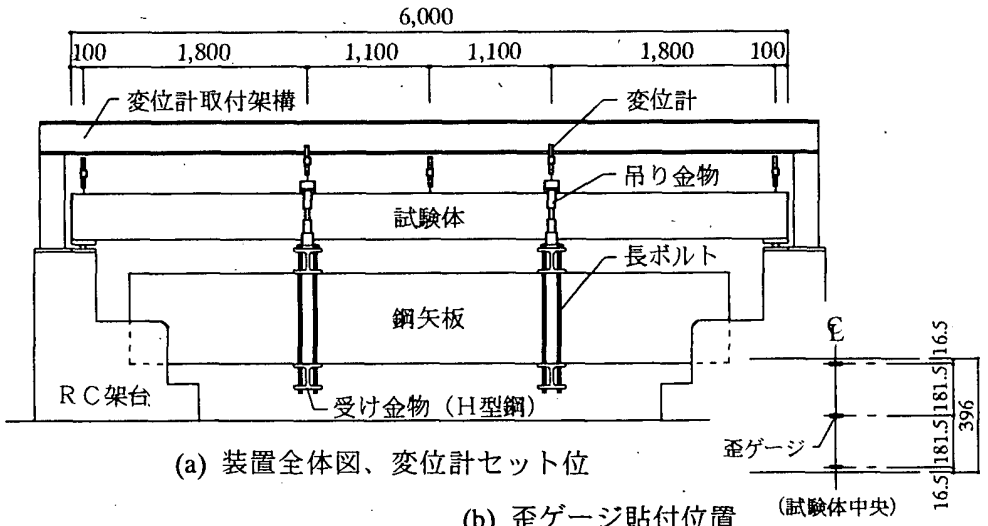

(b) 歪ゲージ貼付位䈯

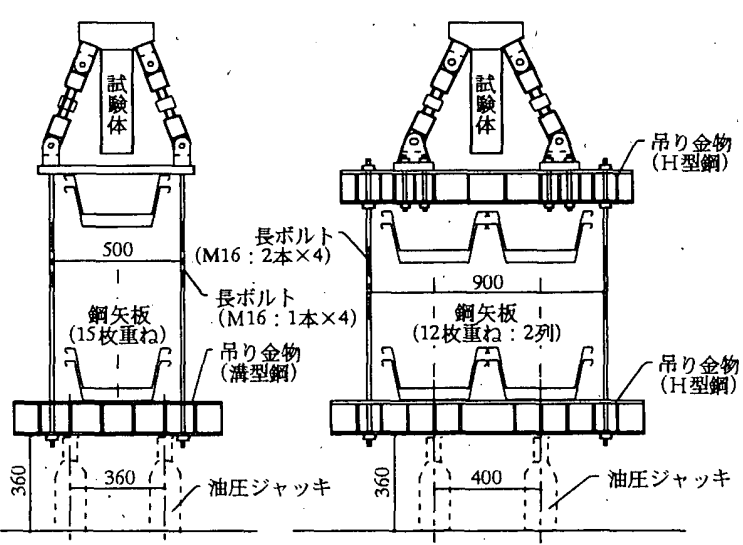

(c) 載荷装置構成 $(\alpha=0.3)$

(d) 載荷装置構成 $(\alpha=0.5)$
れらの変位計は、支持架台の上に架け渡した鉄骨架構に取り付ける。 支持点を測定するのは、支圧に伴う支持点木部の局部変形に対する 補正のためである。又、同種の変位計を不動点にセットし、これに より長期的な電気的変動等の零点修正を行った。測定は一定時間お きとし、載荷開始時点から載荷 1 時間後まで 30 秒間隔、6 時間後ま で 15 分間隔、 1 週間後まで 1 時間間隔、以後は 1 週間から数週間間 隔で測定を行った。載荷後 1 週間後までは機器による連続自動測定 とし、以後はポータブルの小型測定器を用いた。両者の間に測定值 の差異は殆どないことを確認している。応力比 0.5 の試験体につい ては、試験体中央断面に載荷前に歪ゲージを貼付し、曲げ変形性状 を測定した。歪ゲージの貼付位置を図 3 (b)に示す。測定は 24 時間 おきに行い、歪ゲージ用接着剤の有効期間を考慮して、測定は載荷 後 20 日目までとした。

温度及び湿度の測定記録に注連続記録方式の温湿度計を使用した。 温湿度計は試験体近傍に置き、載荷期間中計測を継続した。 なお、定期的な測定とは別に、次の(1) (4)の各時期に短期間の連続 測定を実施した。(1)載荷直後、(2)比較的温湿度の高い夏期（載荷 1 年目及び 2 年目)、応力比 0.5 の試験体については、(3)ひびわれ発 生 (載荷後 1 年半で発生) 後、(4)その半年後の春期。なお、応力比 0.3 の試験体の実験終了時に、除荷、再載荷、再除荷を実施し、ク リープ変形の戻り特性を計測している。

\section{3.クリープ変形挙動}

$3-1$. 変位測定結果

測定期間は、 1991 年 3 月 26 日から 2000 年 6 月 15 日までの 9 年 間以上に亘る。試験体の中央変位と経過時間との関係を図 4 に示す。 変位は中央の変位計の測定值から両支持点変位計の測定値の平均値 を差し引いて補正した値である。変位測定と同時に記録した温度と 湿度のデータを併せて図中に示している。

試験体に完全に荷重がかかった直後 (約 1 分程度)、比較的はっき りと中央変位の增加が収まる時点が認められ、この測定值を初期変 位とした。初期変位は、応力比 0.3 の場合 $17.69 \mathrm{~mm}$ 、応力比 0.5 の場 合 $31.92 \mathrm{~mm}$ で、図 2 に示す静的載荷実験結果による变位よりも若干 小さく評価された。

クリープ変形は大略初期勾配亡、二次勾配の領域に分けられる。 その分岐点は載荷 6 ケ月 (4;000 時間) 頃で、以降変位増加の二次 勾配は低い。ただし、いずれの勾配も応力比が大きい程高い。二次 勾配への折点は、その年の最高温度の時期に一致しており、高湿度 にも対応する。言い換えれば、高温、高湿の山をピークにクリープ 変形が脈動している。以降、影響は小さいが、応力比 0.5 の試験体 では、次に述べるひびわれの影響と重なり、その傾向が認められる。

載荷 1 年半頃、応力比 0.5 の試験体の中央下部に図 5 に示すよう なひび割れを発見した。同図に示すように最下端から 2 枚目のラミ

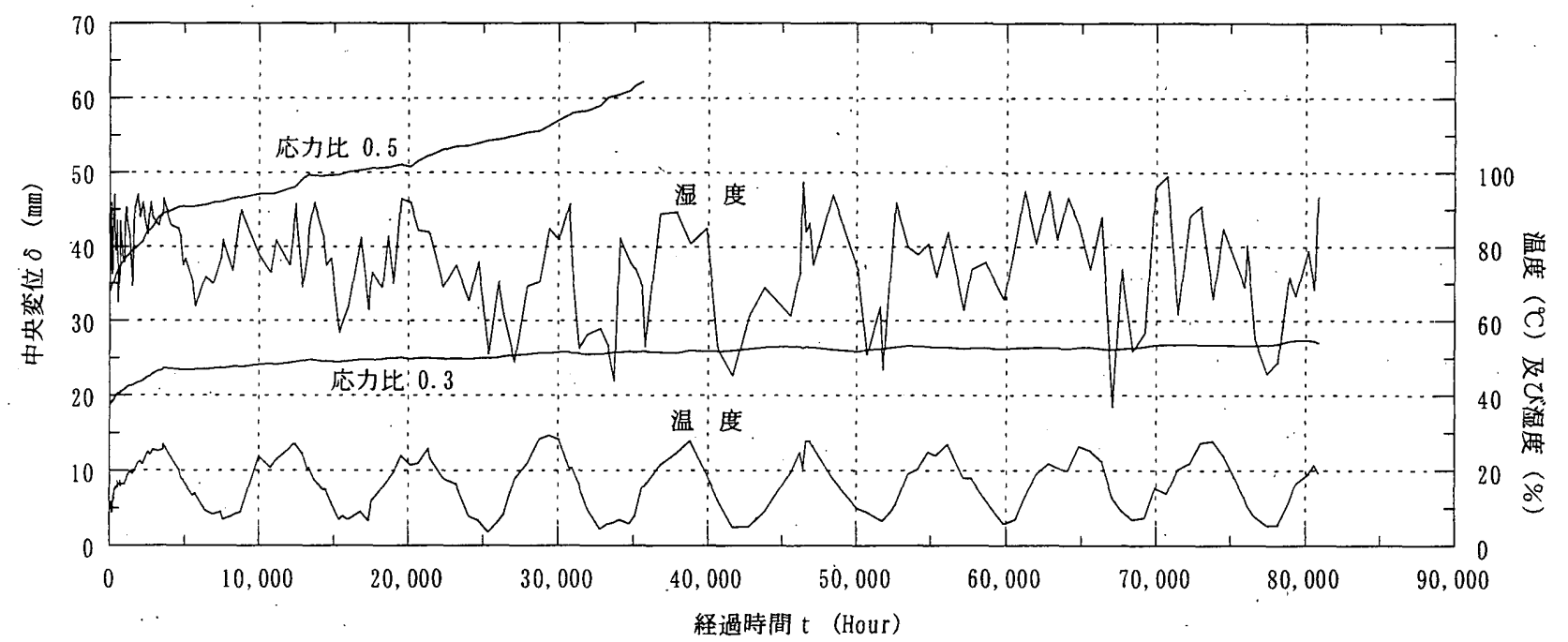

図 4 曲げクリープ変位（9 年間） 
ナに節があり、ひび割れは節の上の 3 枚目のラミナに発生していた。 2 枚目のラミナの節のちょうど反対側の側面にも別の節が存在し、 同様なひび割れが現れている。このひび割れは測定を行った 8 月 24 日（12,410 時間）から9月 14 日（12,910 時間）の間に生じたもの である。ひび割れ発生時点で変位は增加するが、その後 20,000 時間 を越えるまで、ほほひび割れ発生以前の勾配で経過した。しかし 20,000 時間を越えてから勾配が高くなっている。ひび割れのうち横 ひび割れは徐々に進展し、載荷 4 年目の時点 1995 年 3 月 28 日 $(35,110$ 時間）で倍の長さに達した。 3 年半（30,000 時間）経過時には節の 下側にも縦ひび割れが発生し、これが最下端のラミナとの接着面に 至って横方向に進展し始め、載荷 4 年目の時点では約 $120 \mathrm{~mm}$ 離れ た節に達していた。そして同年 4 月 24 日（35,760 時間）にクリー プ破壊した。図 4 では、破壊の直前 4 月 18 日（35,620 時間）に測 定したデータまで示されている。

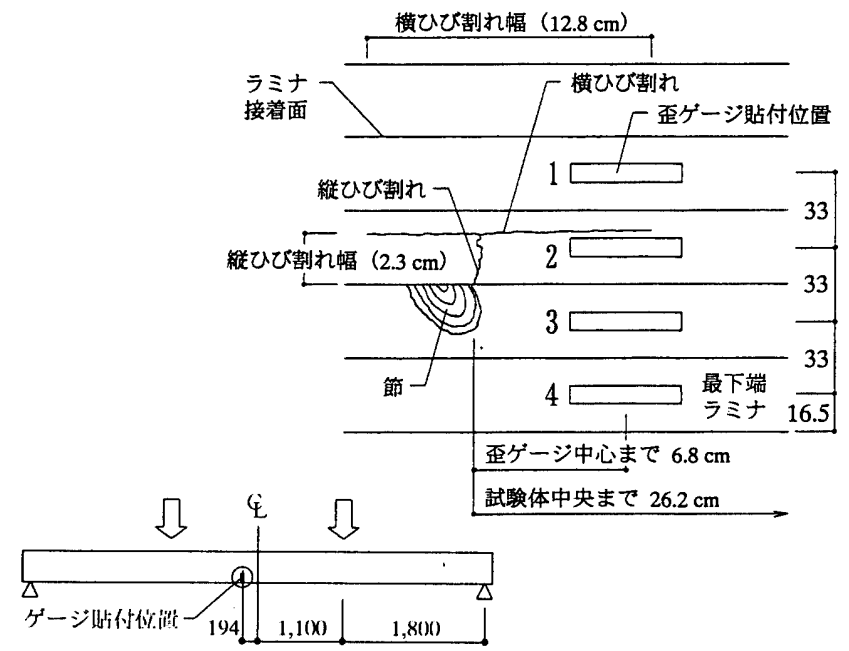

図 5 ひび割れ発生状況と歪ゲージ貼付位置（ $\alpha=0.5$ 試験体）

表 1、表 2 に載荷日から 1 年毎の中央変位と、相対クリープ（中 央変位の初期変位に対する比）及び年間変位増分と初期年度增分比 を応力比別に示した。応力比 0.3 試験体では、対初年度変位增分比 は 5 年間ほほ 1 割程度の值となっているが、 6 年以降温湿度の影響 の割合が大きくなり、ばらついている。応力比 0.5 試験体では、ひ び割れの発生した 2 年目と次の 3 年目の変位增分比を見ると余り変 化が認められないが、4 年目はかなり增大している。

表 1 相対クリープと変位増分（ $\alpha=0.3$ 試験体）

\begin{tabular}{|c|c|c|c|c|}
\hline 測定日 & $\begin{array}{c}\text { 中央変位 } \\
(\mathrm{m})\end{array}$ & $\begin{array}{c}\text { 相対ク } \\
\text { リーフ }\end{array}$ & $\begin{array}{c}\text { 年間変位增 } \\
\text { 分 (mm) }\end{array}$ & $\begin{array}{c}\text { 初年度変 } \\
\text { 位增分比 }\end{array}$ \\
\hline 1991年3月26日 & 17.69 & - & - & - \\
\hline 1992年3月26日 & 23.95 & 1.35 & 6.26 & 1.00 \\
\hline 1993年3月26日 & 24.87 & 1.41 & 0.92 & 0.15 \\
\hline 1994年3月28日 & 25.28 & 1.43 & 0.41 & 0.07 \\
\hline 1995年3月28日 & 25.88 & 1.45 & 0.60 & 0.10 \\
\hline 1996年3月26日 & 26.52 & 1.50 & 0.64 & 0.10 \\
\hline 1997年3月27日 & 26.54 & 1.50 & 0.02 & 0.00 \\
\hline 1998年3月20日 & 26.45 & 1.50 & 0.09 & 0.01 \\
\hline 1999年3月19日 & 26.87 & 1.52 & 0.42 & 0.07 \\
\hline 2000年3月24日 & 27.30 & 1.54 & 0.43 & 0.07 \\
\hline 2000年6月15日 & 27.15 & 1.53. & - & - \\
\hline
\end{tabular}

表 2 相対クリープと変位増分（ $\alpha=0.5$ 試験体）

\begin{tabular}{|c|c|c|c|c|}
\hline 測定日 & $\begin{array}{c}\text { 中央変位 } \\
(\mathrm{mm})\end{array}$ & $\begin{array}{c}\text { 相対ク } \\
\text { リーブ }\end{array}$ & $\begin{array}{c}\text { 年間変位增 } \\
\text { 分 }(\mathrm{mm})\end{array}$ & $\begin{array}{c}\text { 初年度変 } \\
\text { 位增分比 }\end{array}$ \\
\hline 1991年3月26日 & 31.92 & - & - & - \\
\hline 1992年3月26日 & 46.61 & 1.46 & 14.69 & 1.00 \\
\hline 1993年3月26日 & 50.53 & 1.58 & 3.92 & 0.27 \\
\hline 1994年3月28日 & 54.67 & 1.71 & 4.14 & 0.28 \\
\hline 1995年3月28日 & 61.71 & 1.93 & 7.04 & 0.48 \\
\hline 1995年4月18日 & 62.09 & 1.95 & - & - \\
\hline
\end{tabular}

写真 2 に応力比 0.5 試験体のクリープ破壊直後の状況を示す。な お、クリープ破壊の直前に急激な湿度変化があり、温湿度計は 8 時 間で 94\%から 44\%への低下を記録していた。

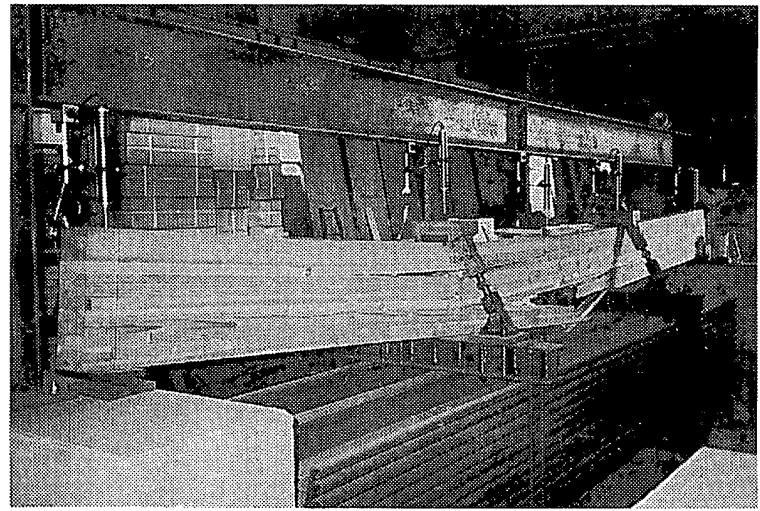

写真 2 クリープ破壊状況（ $\alpha=0.5$ 試験体、 $35,760 \mathrm{~h}$ 経過時）

\section{$3-2$. 時期別詳細挙動}

（1）載荷後 20 日目までの歪挙動

載荷直後からのクリープ変形時の歪量を調べるため、応力比 0.5 の試験体の中央断面に歪ゲージを貼付し、載荷後 20 日間、24 時間 おきに測定した。図 6 にその結果を示す。歪ゲージの貼付位置は、 図 3 (b)に示すように片側側面 3 ヶ所である。試験体のヤング率を静 的実験より求めた值で評価した時、上下測定位置での歪値は 1,700 $\mu$ 程度となる。載荷直後の歪值は引張側で $1,260 \mu$ 、圧縮側で 1,536 $\mu$ であった。計算値より低めの值が測定されており、若干の非対称 性を示した。20日間の経過は、引張側、圧縮側共に歪が僅かずつで はあるが増加していることがわかる。特に載荷後 1 日間の増加が大 きい。20日後の歪值は、それぞれ $1,460 \mu 、-1,670 \mu$ となった。な お、中央の歪值は時間の経過と共に 0 に近づいている。

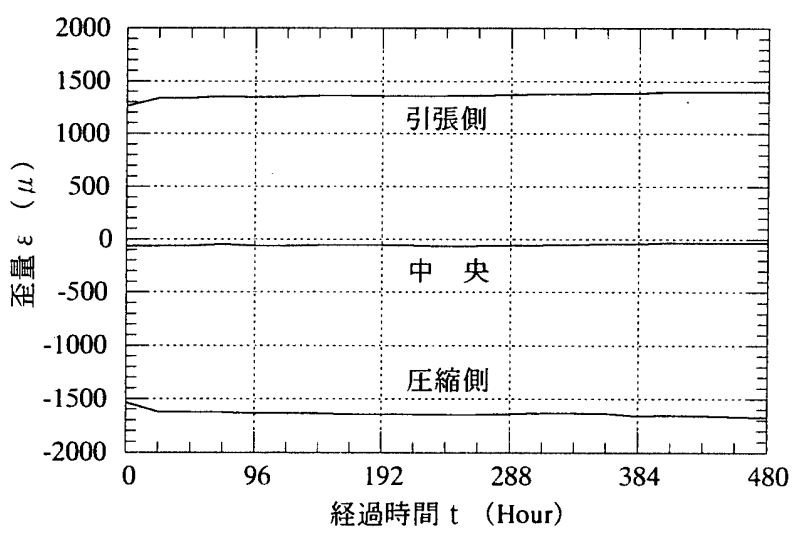

図 6 中央断面丕量（ $\alpha=0.5$ 試験体 $0 \sim 480 \mathrm{~h}$ ) 
（2）載荷 1 年目の夏期に於ける中央変位增分

比較的温湿度の高い時期（夏期）の試験体の動きを調べることを 目的として、1991年 8 月 9 日 16 時 30 分より同 23 日 11 時 30 分ま で約 2 週間、 1 時間おきに計 331 時間変位を連続測定した。これは 載荷後、 3,270 時間から 3,601 時間に相当する。測定は応力比が 0.3 と 0.5 の両方の試験体について行った。図 7 にその結果を示す。試 験体脇にセットした温湿度計による温度と湿度のデータを図中に併 せて示した。縦軸の中央変位增分は、負值が変位の戻る方向で正値 が変位の增える方向である。温度の変化は少ないが、湿度は比較的 高い領域で変動している。同図より試験体のクリープ変位は、ほほ 日周期で小さな増减を繰り返しながら徐々に増加していることがわ かる。両試験体に共通して、夕方から早朝にかけて僅かながら変位 が回復する傾向が認められる。240 時間後湿度がほほ $90 \%$ と高湿度 になったところで両試験体の変位量が大きく伸びているのが確認で きる。 331 時間後の両試験体の変位增分は、応力比 0.3 の試験体で $0.29 \mathrm{~mm} 、 0.5$ の試験体で $0.46 \mathrm{~mm}$ であった。

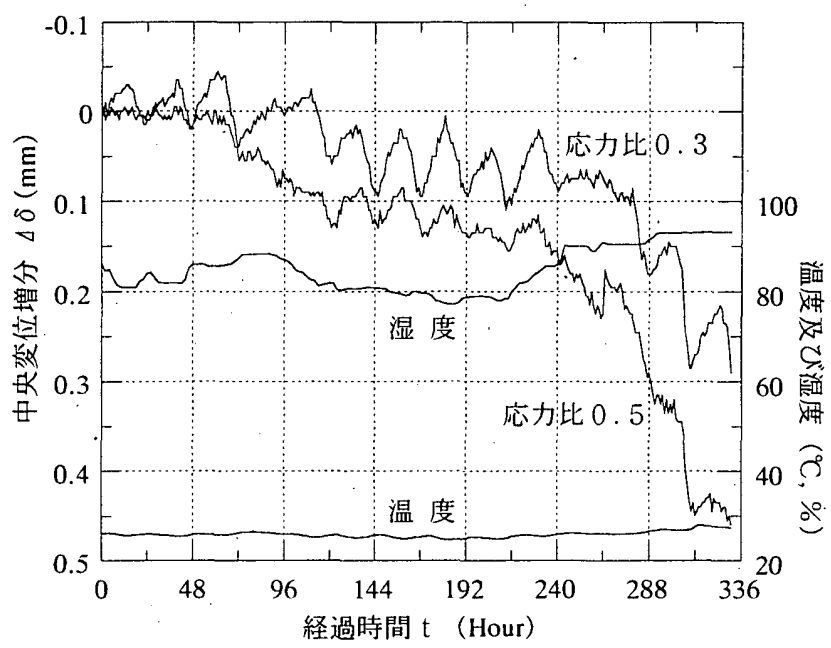

図 7 中央断面歪量 $(3,270 \sim 3,601 \mathrm{~h})$

（3）ひび割れが発生した後の応力比 0.5 の試験体の歪測定

$3-1$ で述べたように: 載荷後約 1 年半の時点で応力比 0.5 の試 験体にひび割れが発生したため、ひび割れ近傍のラミナの歪状況と クリープ変位との関倸を調べるため、最下端から 4 枚目までのラミ ナに図 5 に示すように歪ゲージを貼付し、変位とともに歪量を 1 時 間毎に測定することとした。測定期間は 1992 年 10 月 27 日 13 時よ り 12 月 16 日 12 時までの 50 日間（13,970 15,170 時間）である。 図 8 にその結果を示す。横軸の経過時間は測定開始時を 0 とした。 試験体脇にセットした温湿度計による温度と湿度のデータを図中に 併せて示した。秋期のテータ例である。

変位增分と湿度の関係を見ると、高湿度で変位が増大する関係が ほぼ対応している。大きな節のあるラミナに貼付した歪ゲージ（ゲ 一ジ 3）の歪增分が最も増減の幅が大きく、最大で $250 \mu$ の動きを示 している。逆に最も増減の幅が小さいのはひび割れの入ったラミナ に貼付した歪ゲージ（ゲージ 2）で応力緩和の影響と思われる。歪 增分と湿度の関係を見ると、ゲージ 3 は、雨者の増减が比較的明瞭 に対応していることがわかる。ただし、高湿度で大きく圧縮側に移
行するところから、横ひび割れより下の部分が単独に曲げ抵抗を示 しているものと思わ抽る。

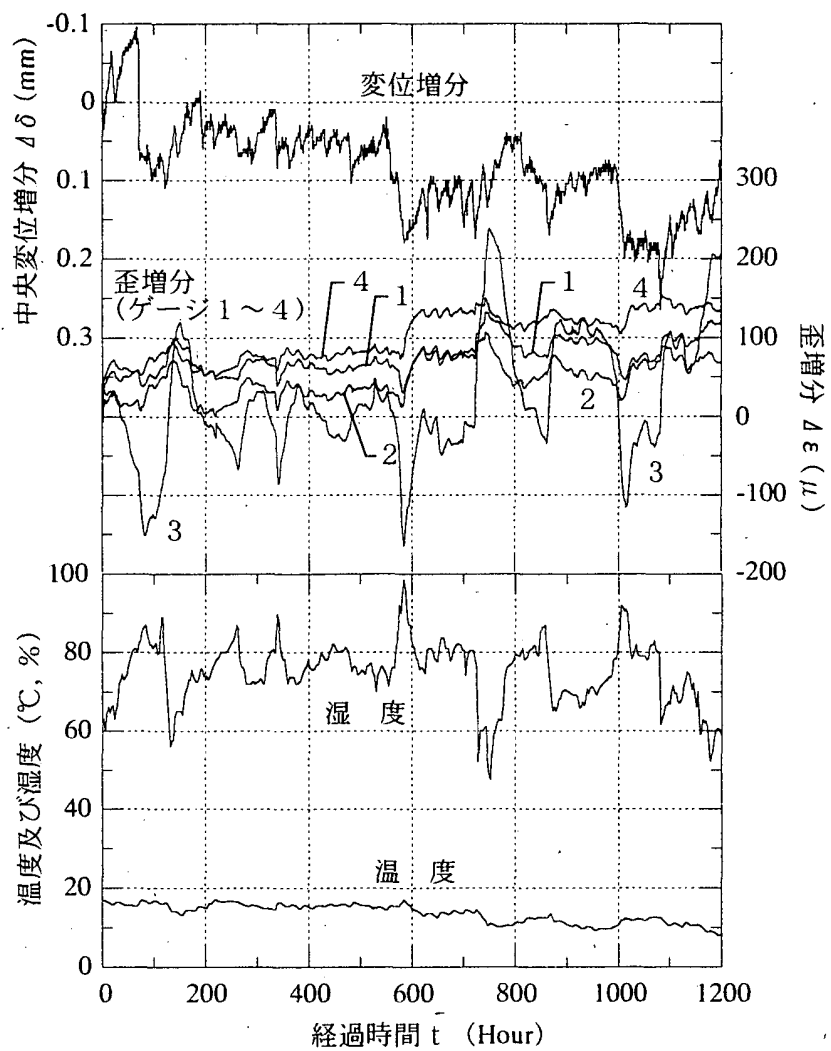

図 8 ひび割れ発生位置の歪と中央変位の増分 $(13,970 \sim 15,170 \mathrm{~h})$

（4）載荷 2 年目の夏期に於ける中央変位增分

載荷 1 年目と同様に比較的温湿度の高い時期（夏期）の試験体の 動きを調べることを目的として、1992 年 8 月 10 日 11 時より同 24 日 11 時までの 2 週間、 1 時間おきに計 336 時間変位を連続測定した。 これは載荷後 12,070 時間から 12,406 時間に相当する。測定は応力 比が 0.3 と 0.5 の両方の試験体について行った。図 9 にその結果を 示す。

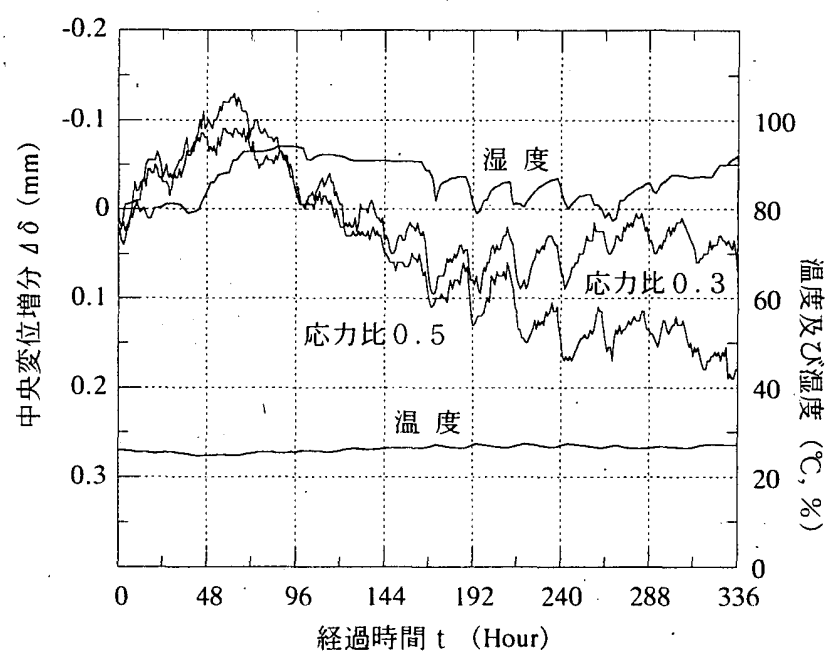

図 9 中央変位增分 $(12,070 \sim 12,406 \mathrm{~h})$ 
2 体の試験体とも、載荷 1 年目と同様にほぼ日周期の小さな增減 を繰り返しながら変化している。夕方から早朝にかけて僅かに変位 が回復するのも載荷 1 年目と同じ傾向である。特に今回は湿度との 対応が比較的明瞭に認められる。70 時間目から 160 時間目あたりま で湿度が高い状態（90\%以上）が続き、この間応力比 $0.3 、 0.5$ の両 試験体とも変位が継続的に増加している。160時間から 300 時間の 間の湿度が $90 \%$ 以下の状態では、変位增分に停滞の傾向が認められ クリープ変形への湿度の影響が大きい。なお、 1 年目の測定結果に 比較して增分量はかなり小さくなっていることが分かる。336 時間 の両試験体の変位増分は、店力比 0.3 試験体で $0.07 \mathrm{~mm} 、 0.5$ の試験 体で 0.18 mmであった。

（5）応力比 0.5 の試験体の載荷 3 年目春期に於ける中央変位増分 応力比 0.5 の試験体につき、ひび割れ発生後ほぼ半年が経過した 1993 年 4 月 8 日 12 時より 6 月 19 日 6 時までの 1,722 時間（約 70 日間)、2 時間おきに変位を連続測定した。これは載荷後 17,857 時 間から 19,579 時間に相当する。図 10 にその結果を示す。温度と湿 度については 3 時間毎の測定とした。但し、温湿度計の電池切れに より $1,281 \sim 1,317$ 時間の間のデータが欠如している。 ひび割れ発生後も変位は日周期の増減を繰り返す。この時期、温度、 湿度とも時間の経過に伴って上昇している。高湿度期間の変位增大 傾向は認められるが、それ以上に全体の変位增大勾配が、ひびわれ の影響も含めて大きくなっている。

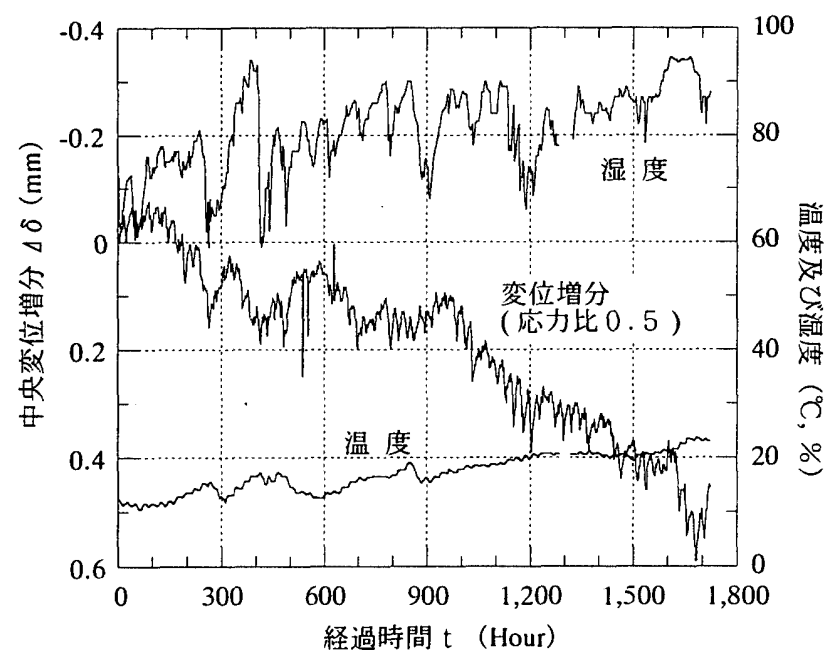

図 10 中央変位増分（17,857 19,579h）

\section{$3-3$. 載荷 9 年後の除荷挙動}

載荷後 9 年 3 ヶ月経た 2000 年 6 月 15 日、午前 10 時応力比 0.3 試 験体の除荷挙動を測定した。除荷プログラムは載荷を含め、図 11 に示す。除荷の方法は載荷の逆手順とし、4 台の手動油圧ジャッキ に全荷重を移行分担させる。

図 11 の載荷一除荷プログラムを参考にして初期剛性に対する各 剛性を比較する。除荷時の剛性は載荷時の初期剛性に対して $2.9 \%$ 高 再載荷、再除荷時の剛性でそれぞれ $0.2 \%$ 高 $8.3 \%$ 高であった。ただ し、後者に対して再除荷後 4 分経過時の值を用いると、 $0.1 \%$ 高程度 となり、いずれもほぼ初期剛性で評価できて、長期の荷重に対する
剛性の劣化は認められなかった。

図 12 は、降荷時のクリープ回復性状である。除荷後ほほ 1 ケ月の 7月 17 日午前 9 時 56 分 (791 時間)まで変形の戻り性状を観測した。 図中除荷時点を原点とし、初期の載荷直後の挙動を変形の方向を逆 にして重ね合せ、破線で示した。除荷に対する実験結果と良く一致 している。6月 15 日以降、この期間の除荷しなかった場合のクリー プ変形が殆ど無視できると考えれば、一般的に言われている重ね合 せの原理(5)の妥当性が評価できる。

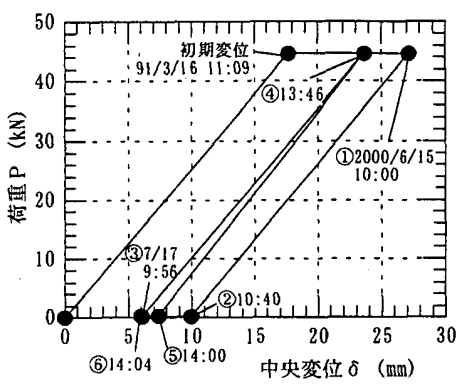

図 11 載荷一除荷経路

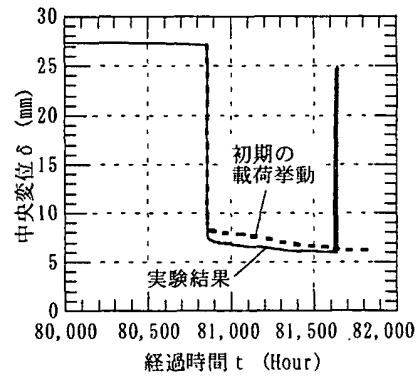

図 12 除荷時のクリープ回復

\section{4. クリープ変形予測}

4-1. 予測式

実大集成材の曲ぼクリープ予測式として、木材のクリープ変形に 関する次の一般式を用いる。

$$
\begin{aligned}
& \delta / \delta_{0}=1+\mathrm{a} / \delta_{0} \cdot \mathrm{t}^{\mathrm{N}}
\end{aligned}
$$

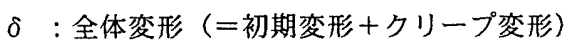

$$
\begin{aligned}
& \delta_{0}: \text { 初期変形 } \\
& \mathrm{t} \text { : 時間 (Hour) }
\end{aligned}
$$

ここに、a，N は定数である。（2）式を対数表示すれば、次式を 得る。

$$
\begin{aligned}
\Delta=\mathrm{A} & +\mathrm{N} \cdot \mathrm{T} \\
\Delta & =\log \left(\delta / \delta_{0}-1\right) \\
\mathrm{A} & =\log \mathrm{a} / \delta_{0} \\
\mathrm{~T} & =\log \mathrm{t}
\end{aligned}
$$

図 13 は、縦軸に相対クリープ増分、横軸に時間をそれぞれ対数で 示した $\Delta$ ーTにとり、実験結果を示したものである。（3）式に従え ば、縦軸との交点を $\mathrm{A}$ とし、勾配 $\mathrm{N}$ なる右上がりの直線となる。測 定值は、いずれの荷重レベルの試験体に於いても類似した折線状態 となっており、載荷初期のばらつきや初年度夏期の高温高湿の影響 を大きく受けるものと思われる。図 4 で述べたように、この初年度 の夏期を過ぎた 4,000 時間（ $\mathrm{T}=3.6 ）$ 以降の図 4 で示される二次勾配 の領域で変形予測を行なうことが望ましいと思われる。

表 3 はクリープ計測データを（2）式で回帰して、定数 A、Nを求 めたものである。対象とする計測期間デー夕を変化させて示した。 応力比 0.3 試験体の初めから最終データまでと、応力比 0.5 試験体 の初めからひび割れの発生した 17 ヶ月目までのデー夕による結果 と、初期の半年分を削除したデタによる結果を比較すると、大き な差があることが分かる。相関係数 R の值は初期デー夕を含む方が 1 に近く、回帰の精度の良いことを示している。ここでデータの内 容をみると、本計測では初期に於けるクリープ変形変動の大きな期 間の計測密度が非常に高い。初めから 1 年までのテータから求めた 
定数は、初期データを削除しなかった場合に近い。従って初期デー 夕を含むと、この初期領域の回帰に偏重し将来予測の精度に対して、 むしろノイズとして㗢くことが分かる。図 13 中に初期からの全デー 夕による回帰直線と、半年間のデータを削除した回帰直線を示した。 これからも図 4、図 13 で述べた初期テー一タ削除が、将来予測式の 精度の向上に効果があるといえる。

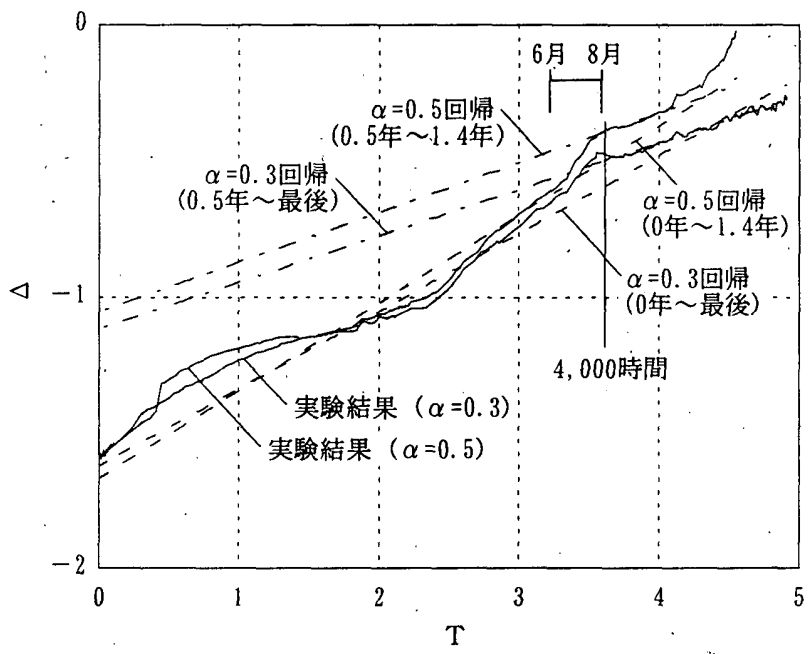

図 13 両対数表示測定結果.

\section{4-2. 定数の決定}

定数設定にはこれまでの考察から半年後からの安定領域の計測テ 一タによるが、計測期間は短い程効率がよい。この観点から、半年 後以降、データ抽出期間を適宜増加させ、それぞれのケースに対す る定数より計測期間と精度との関係を検討する。なお比較する精解 値として、先に述べた初期の半年間のデータを削除した全有効デー
タにより求めた次の定数を用いることとする。

応力比 $\alpha=0.3$ 試験体： $\mathrm{A}=-1.115 \mathrm{~N}=0.171$

応力比 $\alpha=0.5$ 試験体： $\mathrm{A}=-1.053 \mathrm{~N}=0.183$

図 14 は 4,000 時間以降の領域を拡大した計測結果である。全有効 テータの範囲で：ほほ線形関係にあることが認められる。同図中に 有効データ 6 ケ月と 1 年の回帰直線を 600,000 時間まで示した。前 者は危険側の予測となる。この領域はクリープ変形そのものの変動 より温湿度変動の影響が大きいものと考えられ、少なくとも回帰す るデータは季節の.1 サイクルを含ませることが望ましい。

応力比 0.3 試験体に対し、より安定領域として初期 1 年間のデ夕を削除した場合の、以後 6 ケ月のデータでは、データ数が少ない 上に変位の増減が影響して精度が得られていない。初期データのば らつきの削除として半年間程度のデータを無視すると同時に、以降 の回帰のためのデータは少なくとも 1 年間を必要とする。この最短 観測により評価される定数は次のようになる。

応力比 $\alpha=0.3$ 試験体： $A=-1.154 \quad \mathrm{~N}=0.180$

応力比 0.5 試験体では初期の半年間デー夕の削除により、ひび割 れ発生までの有効データは 11 ケ月であり、季節 1 サイクルをほほ満 足する最短観测といえる。

60 年後のクリープ変形の予測值を、設定された定数から（2）式 より求める。応力比 0.3 試験体に対し精解值を代入すれば相対クリ ープは次のように算出できる。

$$
\delta /\left.\delta_{0}\right|_{\alpha=0.3}=1+0.077(60 \times 365 \times 24)^{0.171}=1.732
$$

最短観測テータによる相対クリープは次の值となる。

$$
\delta / \delta o_{\alpha=0.3}=1+0.070(60 \times 365 \times 24)^{0.180}=1.750
$$

長期荷重レベルでは、初期変形に対して $75 \%$ 程度クリープによる 変形增大が予測される。これは気乾状態で $100 \%$ 、湿潤・乾燥の繰 返し状態で $200 \%$ とする学会規準(7)で示されるクリープ変形值より

\begin{tabular}{|c|c|c|c|c|c|c|}
\hline 回帰分析期間 & デー夕数 & 係数 $\mathrm{a}$ & 係数 $\mathrm{a} / \delta_{0}$ & 係数 $A=\log \left(\mathrm{a} / \delta_{0}\right)$ & 係数 $\mathrm{N}$ & $\overline{\mathrm{R}}$. \\
\hline 0 年〜 1年 & 305 & 0.4067 & 0.0230 & -1.6385 & 0.3037 & 0.9876 \\
\hline 0 年〜最後 & 414 & 0.4207 & 0.0238 & -1.6237 & 0.2862 & 0.9917 \\
\hline 0.5 年〜 0.58 年（1ケ月データ） & $\overline{4}$ & 14.485 & 0.8188 & -0.0868 & -0.1073 & 0.7418 \\
\hline 0.5 年 0.67年（2ヶ月データ） & 6 & 4.7044 & 0.2659 & -0.5752 & 0.0254 & 0.2194 \\
\hline 0.5 年〜0.75年（3ヶ月データ） & 7 & 4.1030 & 0.2319 & -0.6346 & 0.0415 & 0.4608 \\
\hline 0.5 年〜1年（6ヶ月データ） & 12 & 2.3058 & 0.1303 & -0.8849 & 0.1090 & 0.9094 \\
\hline 0.5 年〜1.5年（1年データ） & 18 & 1.2421 & 0.0702 & -1.1536 & 0.1803 & 0.9541 \\
\hline 0.5 年 2 年 (1年半 - -夕 $)$ & 29 & 1.2929 & 0.0731 & -1.1362 & 0.1759 & 0.9677 \\
\hline 0.5 年 $\sim 2.5$ 年 (2年テータ $)$ & 38 & 1.3407 & 0.0758 & -1.1204 & 0.1718 & 0.9751 \\
\hline 0.5 年〜最後 & 121 & 1.3587 & 0.0768 & -1.1 .146 & 0.1706 & 0.9803 \\
\hline 1 年〜1.5年 $(6$ ケ月データ $)$ & 7 & 0.3849 & 0.0218 & -1.6624 & 0.3065 & 0.9623 \\
\hline 1 年〜2年（1年データ） & 18 & 1.3530 & 0.0765 & -1.1164 & 0.1714 & 0.8424 \\
\hline
\end{tabular}

表 3 (a) $\alpha=0.3$ データによる定数設定（Hour）

\begin{tabular}{|c|c|c|c|c|c|c|}
\hline 回帰分析期間 & 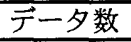 & 係数 $\mathrm{a}$ & 係数 $a / \delta_{0}$ & 係数 $\mathrm{A}=\log \left(\mathrm{a} / \delta_{0}\right)$ & 係数 N & $\mathrm{R}$ \\
\hline 0 年 1 年 & 335 & 0.6851 & 0.0215 & -1.6683 & 0.3228 & 0.9839 \\
\hline 0年〜1.4年（ひび割れまで） & 341 & 0.6831 & 0.0214 & -1.6695 & 0.3244 & 0.9881 \\
\hline 0.5 年〜 0.58 年（1ヶ月データ） & 4 & 11.702 & 0.3666 & -0.4358 & 0.0167 & 0.1983 \\
\hline 0.5 年〜0.67年（2ヶ月データ） & 6 & 11.787 & 0.3693 & -0.4327 & 0.0158 & 0.3659 \\
\hline 0.5 年〜0.75年（3ケ月データ） & 7 & 8.4063 & 0.2634 & -0.5795 & 0.0556 & 0.7682 \\
\hline 0.5 年〜1年（6ケ月デー夕） & 12 & 4.3225 & 0.1354 & -0.8683 & 0.1335 & 0.9538 \\
\hline 0.5 年〜 1.4 年 (11ヶ月デー夕) & 18 & 2.8279 & 0.0886 & -1.0526 & 0.1825 & 0.9754 \\
\hline 1 年〜1.4年（5ヶ月デー夕） & 7 & 1.3434 & 0.0421 & -1.3759 & 0.2629 & 0.9627 \\
\hline
\end{tabular}

表 3 (b) $\alpha=0.5$ テータによる定数設定（Hour） 


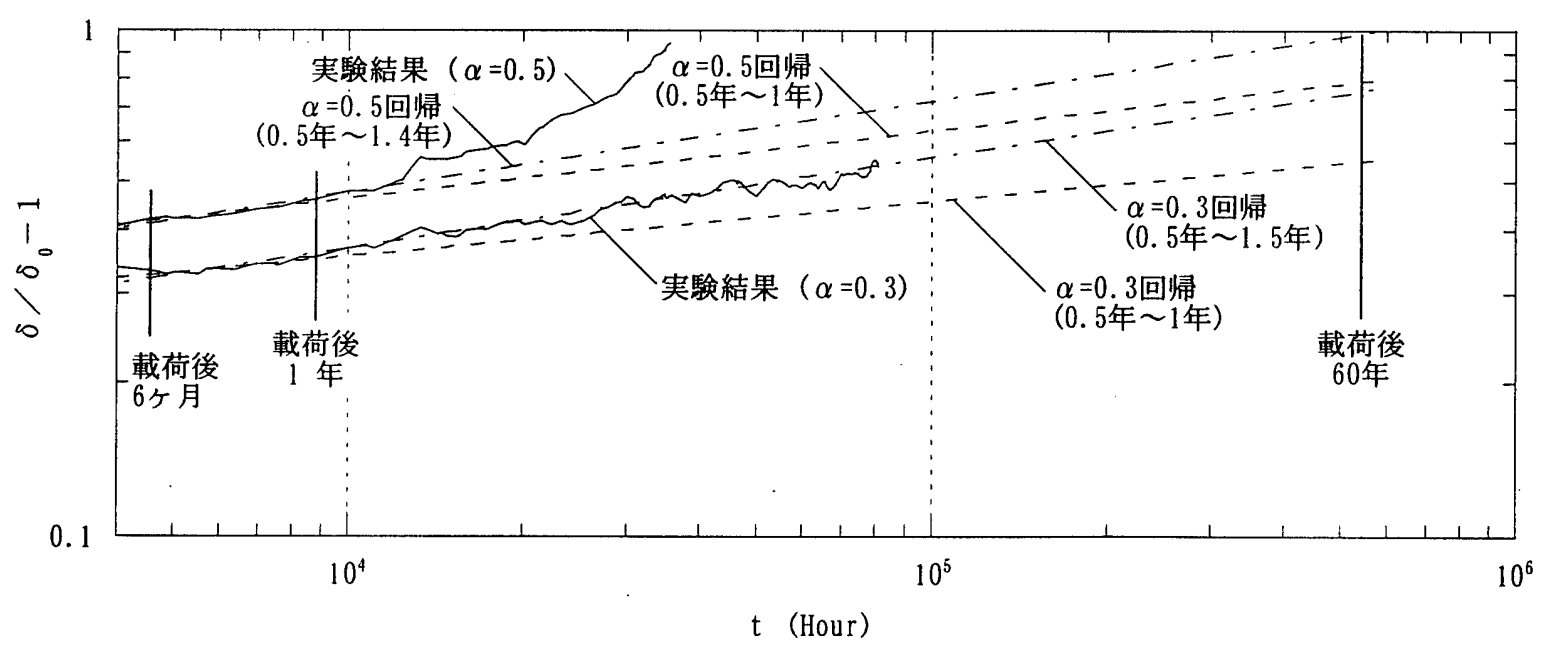

図 14 クリープ変形予想

かなり低い。

応力比 0.5 試験体が仮にクリープ破壊をしないとすれば、 $\delta /\left.\delta_{0}\right|_{\alpha=0.5}=1+0.089(60 \times 365 \times 24)^{0.183}=1.991$

となり、クリープ限度の荷重レベルで、一般に設計において未乾燥 材のクリープで評価される初期変形の 2 倍の值に対応する。

\section{5. 結}

外気にも接する屋内無空調環境に置かれた実大の米松集成材に、 長期許容応力度とクリープ限度の荷重レベルを載荷した場合のクリ ープ挙動を報告するとともに、クリープ変形予測について考察した。 以下にその概要を示す。

・クリープ挙動について

(1) クリープ変形は日周期で增堿を繰返す。

(2) 温湿度の影響を大きく受け、特に夏季の高温・高湿時期にクリ 一プ変形性状に山が認められる。

(3) クリープ限度の応力比 0.5 試験体は載荷 1 年半後にひび割れが 発生し、4 年後にクリープ破壊に至った。

（4）長期荷重レベルの応力比 0.3 試験体における載荷後 9 年 3 ケ月 時点の除荷挙動から、一般的に言われている重ね合せの原理 の妥当性が評価できた。

（5）また除荷時、再載荷時の剛性劣化は認められなかった。 ・回帰によりクリープ予測する場合に於いて

(6) 載荷後半年間程度の初期データは、将来予測に対しノイズ効 果となるため削除することが望ましい。

(7) 少なくとも回帰に用いる観測データは、季節の 1 サイクルを 含んだ 1 年以上の期間分が必要である。

（8）長期荷重レベル（応力比 0.3）を受ける実大米松集成材の湿潤・ 乾燥を繰返す環境下での 60 年後のクリープ変形は、(2)式又は (3)式によれば初期変形の $75 \%$ 程度と予想される。

\section{謝辞}

本クリープ実験の一部は、（財）日本住宅・木材技術センターによ り設置された集成材構造委員会（平成 3 年度〜 5 年度 : 委員長有馬 孝禮東京大学教授）により実施されたものである。

\section{参考文献}

（1）㚼中公臌、木村 街、楠寿博、太田道彦他 3 名: 集成材の曲げクリー プ性状に関する実験的研究、日本建築学会大会学術講演梗概集、pp.21 $\sim$ pp.22、1992 年 8 月

（2）楠寿博、木村 衛、太田道彦、畑中公樹他 3 名: 集成材の曲げクリー プ性状に関する実験的研究（その 2 ）、日本建築学会大会学術講演梗概 集、pp.917〜 pp.918、1993 年 9 月

(3) 楠 寿博、木村 街、太田道彦、畑中公樹他 3 名: 集成材の曲攻クリ一 プ性状に関する実験的研究 (その 3 )、日本建築学会大会学術講演梗概 集、pp.25〜pp.26、1996 年 9 月

（4）（財）日本住宅木材・技術セン夕ー: 技術開発推進事業報告書 集成材構 造開発、1992年 3 月 1994 年 3 月

（5）日本建築学会：木質楧造設計規準・同解説、1995 年

（6）杉山英男:木材の曲げ強度と剛性に及ぼす倚重時間の影響、日本建筮 学 会論文集第 52 号、pp.85〜pp.94、1956 年 3 月

（7）沢田 稔：木材梁に関する研究（第 4 報）曲げクリープ試験（1）、林 業試験場研究報告、No.98、pp.85 pp.116、1957 年

(8) 竹山譮三郎、久田俊彦、竹之内清次: 木棈造の長期強度について, 日本 建築学会論文集第 39 号、pp.18〜pp.27、1949 年 11 月

（9）森 三郎:死荷重に対する木材の応力に就いて、日本林学会誌、Vol.16、 No.1、pp.85 pp.88、1934 年

（10）久田俊彦: 木材の長期荷重に対する強度站に断面欠損の影響、日本建築 学会研究報告集第 9 号、pp.81 pp.84、1950 年 11 月

(11) 杉山英男: Experimental Data on the Prediction of the Creep Limit of Wood in Bending from Creep and Creep Recovery.Tests、明治大学工学部研究報告、 No.11、pp.13 53、1958 年

(12) Jelena S. Mladen H. : Creep Factors for Wood and Glulam Structures. Proceedings of the 1990 International Timber Engineering Conference Vol.2、 pp.416 pp.423、1990 年 10 月

(13) Ranta-Maunus Aipo、Kortesmaa Markku : Creep of timber during eight years in natural environments. Proceedings of the World Conference on Timber Engineering、2000年 8 月

(14) 高橋茂男、北村俊夫、森 拓郎、笹川 明他 1 名: 大気下の集成材はり、 接合部、建物のクリープ変形と季節変動、日本建築学会構造系論文集 第 551 号、pp.87 pp.94、2002 年 1 月

(15) 杉山英男 : 木材のクリープ限度について、第 27 回日本建築学会関東支 部研究報告集、pp.5 pp.8、1960 年 1 月

（16）有馬孝糟、佐藤雅俊、益田恵吾 : 木質材料及び部材の長期耐力評価に関 する研究、建築研究報告、No.95、1981 年 3 月

(17) 有馬孝禮、丸山則義: 木材および木質材料のクリープ変形とクリープ破 壊、第 52 回日本建築学会関東支部研究報告集、pp.325 pp.328、 1986 年

（18）杉山英男：建築構造学大系 22 木棈造、彰国社、1971 年 （2002年 4 月 30 日原稿受理， 2002 年 8 月 12 日採用決定） 